\title{
ABSORPTION OF FERROUS AND FERRIC RADIOACTIVE IRON BY HUMAN SUBJECTS AND BY DOGS ${ }^{1}$
}

\author{
BY CARL V. MOORE, REUBENIA DUBACH, VIRGINIA MINNICH, \\ AND HAROLD K. ROBERTS
}

(From the Department of Internal Medicine, Washington University School of Medicine, St. Louis)

(Received for publication March 6, 1944)

Much evidence has been accumulated to indicate that human subjects absorb ferrous more readily than ferric iron. There is agreement among physicians and clinical investigators that patients with hypochromic anemia respond with maximal hemoglobin production to amounts of soluble ferrous salts containing only one-fourth to one-sixth the quantity of iron which must be given in the form of a soluble ferric salt to produce comparable therapeutic effects (1 to 10 ). Furthermore, studies of iron absorption have regularly shown that the bivalent form of the metal is more completely assimilated (11 to 13 ). In studies made on experimental animals, however, results have been less consistent. Many investigators have found that laboratory animals absorb both valence forms of iron equally well (14 to 18), several claim superiority for ferric iron $(19,20)$, while others have either observed greater assimilation of the ferrous form or have claimed that only ferrous iron was absorbed (21 to 25). This lack of agreement in the animal studies may be traced in part, at least, to the different methods used for measuring absorption and to the inadequacy of several of the technics. One is impressed by the fact that the workers in the two laboratories in this country which have studied iron metabolism in animals most intensively are convinced that there is no difference in the degrees to which ferrous and ferric salts are absorbed (14 to 16 ).

Consequently, a disagreement has resulted between the clinical and some of the animal investigators as to the form in which iron is taken up by the body from the intestinal tract. There are two possible explanations for this difference of opinion: either one group of workers is in error, or else both are correct and animals absorb

\footnotetext{
1 These studies were made with the help of grants received from Mr. Edward Mallinkrodt, Jr., and the John and Mary R. Markle Foundation.
}

ferric iron more efficiently than do human subjects. With the development by Hahn and his associates of an accurate method of measuring iron absorption by using the radioactive isotope of iron, it is now possible to determine experimentally which of the two explanations is correct. This communication describes such studies made on (1) normal and iron-deficient dogs, and (2) normal and iron-deficient human subjects. Dogs were selected because in these animals Whipple, Hahn, and their associates have "never observed any significant difference in iron absorption whether the metal was given as a ferric or ferrous salt" (26). The data reported below demonstrate that human subjects almost always show significantly greater assimilation of radioactive ferrous salts than of ferric, whereas dogs frequently absorb both valence forms equally well.

\section{METHODS}

The validity of the technic for quantitating the amount of iron absorbed from a given dose of radioactive iron has been established by demonstrations that (1) the absorbed iron is rapidly synthesized into hemoglobin and appears in the peripheral blood (26 to 29) where its radioactivity can be measured; and (2) excretion of the absorbed iron during the period of study is minimal $(30,31)$. We have been able to confirm the first of these demonstrations. Our curves for the appearance of radicactive iron in the red cells are comparable to those of other investigators. The use of the method also requires acceptance of the postulate, true so far as is known, that the physiological properties of a radioactive isotope are identical with those of the stable form of the element (32). The assumption that the amount of the isotope which appears in the peripheral blood represents the total amount absorbed does not intreduce a large error: that portion which remains in the tissues is not easily determined, but it appears to be small (27).

The human subjects used in this study were: (1) healthy male medical students or laboratory workers who had suffered no known blood loss and who had not served as donors for transfusions; and (2) patients in the Barnes Hospital who volunteered as subjects. The animals were mongrel dogs, kept in individual metabolism cages and fed either the salmon bread diet of Whipple (33) or Purina 
dog chow. Four dogs were depleted of their iron reserves by systematic bleeding, 3 times a week for several months. During the period of depletion, they were fed either the salmon bread diet or milk and bread supplemented with brewer's yeast or a vitamin B-complex concentrate.

The radioactive iron $\left(\mathrm{Fe}^{59}\right)$ used in the experiments was prepared in the Washington University Cyclotron by deuteron bombardment of iron.2 By using a probe prepared by electroplating a thin layer of iron on copper, radioactive iron of very high specific activity was formed. Because considerable amounts of radioactive copper, cobalt, and manganese are formed during the bombardment, precautions were taken to purify the iron and free it of these other radioactive substances. The iron was dissolved by dipping the copper probe in concentrated $\mathrm{HCl}$; the solution was then diluted so that the acid concentration was about $1 \mathrm{~N}$, the copper was precipitated with $\mathrm{H}_{2} \mathrm{~S}$, and the precipitate was removed by filtration. The filtrate was next heated and, if no further cloudiness appeared, boiled to expel the $\mathrm{H}_{2} \mathrm{~S}$. The iron in the filtrate was re-oxidized to the ferric state by the addition of 30 per cent $\mathrm{H}_{2} \mathrm{O}_{2}$ to the hot solution. It was then precipitated with ammonium hydroxide. The $\mathrm{Fe}(\mathrm{OH})_{2}$ was thrown down by centrifugation and dissolved in $6.4 \mathrm{~N} \mathrm{HCl}$. Small amounts $\left(20 \mathrm{mgm}\right.$.) of inert $\mathrm{CoCl}_{2}$ and $\mathrm{MnCl}_{2}$ were added as carriers. Subsequent purification was accomplished by either of the following 2 methods, the second of which has been used in the more recent experiments. Both methods were apparently equally satisfactory.

1. The iron was extracted from the $6.4 \mathrm{~N} \mathrm{HCl}$ solution by continuous extraction with ethyl ether. The ether extract was thoroughly washed with $6.4 \mathrm{~N} \mathrm{HCl}$ to remove traces of cobalt and manganese which had been carried over into the ether layer. The ether extract was then evaporated to dryness and the $\mathrm{FeCl}_{3}$ taken up in $\mathrm{HCl}$.

2. The iron was purified by repeated precipitation with pyridine (34). Before each precipitation, $20 \mathrm{mgm}$. each of $\mathrm{CoCl}_{2}$ and $\mathrm{MnCl}_{2}$ were added as carriers. Precipitations were made until the supernatant solution showed no activity when measured with a Geiger-Müller counter. The iron was then taken up in $\mathrm{HCl}$. The freedom of the purified radioactive iron solution from radioactive elements other than the 47-day iron was confirmed by the shape of the decay curve.

The dose of iron given varied from 1 to $4 \mathrm{mgm}$. per $\mathrm{kgm}$. of body weight and was administered after a 12-hour fast. Dogs were fed the material by stomach tube. Precautions were taken to have all of the iron of a given dose in the state of valence desired. The solution of radioactive ferric chloride was heated and oxidized with 2 drops of concentrated nitric acid, then cooled, and partially neutralized with sodium hydroxide to a $\mathrm{pH}$ of about 3 . The solution of ferrous salt was prepared by reducing the ferric salt with ascorbic acid, immediately before it was given.

Samples of dog blood were obtained by puncture of one of the femoral arteries; specimens from the human subjects

2 The first two samples of iron used were supplied through the courtesy of Dr. Ernest Lawrence and Dr. M. Kamen of the University of California. were obtained by venepuncture in the usual manner. The red cells were thrown down by centrifugation and were digested in a Kjeldahl flask with concentrated $\mathrm{H}_{2} \mathrm{SO}_{4}$ and 30 per cent hydrogen peroxide. The iron was precipitated from the digest as ferric hydroxide, in the manner described by Hahn (27). After several reprecipitations, the iron hydroxide was dissolved in $0.2 \mathrm{cc}$. of $6 \mathrm{~N} \mathrm{HCl}$ and was electroplated from a bath of 3 parts saturated ammonium oxalate solution and 1 part saturated oxalic acid solution, at a current of 1 ampere. The anode was a strip of platinum; the cathode was a copper disc to which had been soldered a brass stem. In order to have all the iron electroplated on the face of the copper disc, a disc of bakelite (with a center hole to slip over the brass rod) was cemented to the back with Glyptal.: The brass rod was also painted with Glyptal to a distance of $1 \mathrm{~cm}$. from its junction with the bakelite disc. During the electroplating, the cathode was rotated just below the surface of the solution by an electric stirrer. In order to get a firm deposit of electrolytic iron, 2 to 5 mgm. of inert iron as ferric chloride were added to the iron from each blood sample. Electroplating was continued until the bath became iron-free, as determined by testing with ammonium sulfide solution. This generally required 2 hours. The method is similar to the one described by Ross and Chapin (35).

Radioactivity measurements were made with a GeigerMuller counter having a scale of 8 . A dip type of Bale tube was used at first with the iron dissolved in exactly 2 cc. of concentrated $\mathrm{HCl}(36)$, but soon after the observations were begun, change was made to a more sensitive bellshaped counter tube with a mica window.4 The iron, isolated from the red cells and electroplated on a copper disc of the same diameter as the window, was placed in a fixed position immediately below the window of the counter tube. By using this technic to replace a glass-walled dipping type of counter, a 30 -fold increase in sensitivity was gained.

In addition to the radioactivity measurements, red blood cell counts were made with equipment standardized by the U. S. Bureau of Standards, hemoglobin determinations were made with the Evelyn photometer, hematocrit values were obtained in Wintrobe tubes centrifuged for 20 minutes at 3,000 r.p.m.

When the percentage of the dose absorbed was calculated, the blood volume was arbitrarily assumed to be 80 cc. per kgm. This assumption was probably no more inaccurate, as far as the red cell volume is concerned, than would have been an estimation of the blood volume by the standard dye procedures (37).

It will be observed that the figures given for the percentage of absorption refer to a single dose of iron, either in the

\footnotetext{
Made by the General Electric Company.

A helium-filled counter has been developed by Dr. Arthur Kip and Dr. Robley Evans of the Massachusetts Institute of Technology. We are indebted to them for supplying us with these tubes. Dr. Alex Langsdorf, Jr., of Washington University, has also furnished us with a bell-type counter filled with argon and alcohol which has a high sensitivity.
} 
TABLE I

Absorption of ferric and ferrous iron by normal dogs

\begin{tabular}{|c|c|c|c|c|c|c|c|c|c|c|}
\hline Dog & Date & wt. & R.B.C. & Hgb. & Cell vol. & Dose of $\mathrm{Fe}$ & $\begin{array}{c}\text { Valence } \\
\text { of } \\
\text { iron }\end{array}$ & Radioactivity & $\begin{array}{l}\text { Labeled iron } \\
\text { in blood } \\
\text { stream* }\end{array}$ & $\begin{array}{l}\text { Ratio of amount } \\
\text { of } \mathrm{Fe}^{++} \text {to } \\
\mathrm{Fe}^{+++} \text {absorbed }\end{array}$ \\
\hline \multirow{3}{*}{32} & & $\mathrm{kgm}$. & millions & grams & per cent & $\underset{\mathrm{kgm} .}{\operatorname{mgm} . \text { per }}$ & & $\begin{array}{c}\text { counts per min. } \\
\text { of total dose }\end{array}$ & per cent & \\
\hline & $\begin{array}{l}6 / 8 / 43 \\
6 / 23 / 43\end{array}$ & 33 & $\begin{array}{l}6.15 \\
5.72\end{array}$ & $\begin{array}{l}15.3 \\
13.8\end{array}$ & $\begin{array}{l}46 \\
43\end{array}$ & $\begin{array}{l}1 \\
1\end{array}$ & $\begin{array}{l}\mathrm{Fe}^{+++} \\
\mathrm{Fe}^{++}\end{array}$ & $\begin{array}{r}10,800,000 \\
8,775,000\end{array}$ & $\begin{array}{l}1.9 \\
5.9\end{array}$ & 3.1 \\
\hline & $\begin{array}{l}8 / 13 / 43 \\
8 / 25 / 43\end{array}$ & 32.2 & $\begin{array}{l}6.41 \\
6.56\end{array}$ & $\cdot \begin{array}{l}16.8 \\
-17.0\end{array}$ & $\begin{array}{l}49 \\
48\end{array}$ & $\begin{array}{l}1 \\
1\end{array}$ & $\begin{array}{l}\mathrm{Fe}^{+++} \\
\mathrm{Fe}^{++}\end{array}$ & $\begin{array}{l}7,212,000 \\
6,300,000\end{array}$ & $\begin{array}{l}6.0 \\
5.0\end{array}$ & 0.8 \\
\hline 33 & $\begin{array}{l}8 / 27 / 43 \\
9 / 10 / 43\end{array}$ & 16.4 & $\begin{array}{l}5.98 \\
5.76\end{array}$ & $\begin{array}{l}16.5 \\
14.0\end{array}$ & $\begin{array}{l}47 \\
40\end{array}$ & $\begin{array}{l}1 \\
1\end{array}$ & $\begin{array}{l}\mathrm{Fe}^{++} \\
\mathrm{Fe}^{+++}\end{array}$ & $\begin{array}{l}4,160,000 \\
3,290,000\end{array}$ & $\begin{array}{l}0.8 \\
0.3\end{array}$ & 2.7 \\
\hline \multirow[t]{2}{*}{34} & $\begin{array}{l}8 / 27 / 43 \\
9 / 10 / 43\end{array}$ & 11.8 & $\begin{array}{l}6.51 \\
6.60\end{array}$ & $\begin{array}{l}15.8 \\
15.8\end{array}$ & $\begin{array}{l}48 \\
45\end{array}$ & $\begin{array}{l}1 \\
1\end{array}$ & $\begin{array}{l}\mathrm{Fe}^{+++} \\
\mathrm{Fe}^{++}\end{array}$ & $\begin{array}{l}4,180,000 \\
3,280,000\end{array}$ & $\begin{array}{l}1.3 \\
7.8\end{array}$ & 6.0 \\
\hline & $\begin{array}{r}9 / 28 / 43 \\
10 / 8 / 43\end{array}$ & & $\begin{array}{l}6.21 \\
6.20\end{array}$ & $\begin{array}{l}15.8 \\
16.1\end{array}$ & $\begin{array}{l}46 \\
45\end{array}$ & $\begin{array}{l}1 \\
1\end{array}$ & $\begin{array}{l}\mathrm{Fe}^{+++} \\
\mathrm{Fe}^{++}\end{array}$ & $\begin{array}{l}1,378,000 \\
1,226,400\end{array}$ & $\begin{array}{l}7.5 \\
8.8\end{array}$ & 1.2 \\
\hline \multirow[t]{2}{*}{38} & $\begin{array}{l}10 / 22 / 43 \\
11 / 5 / 43\end{array}$ & 12.7 & $\begin{array}{l}6.35 \\
5.64\end{array}$ & $\begin{array}{l}14.3 \\
13.8\end{array}$ & $\begin{array}{l}44 \\
43\end{array}$ & $\begin{array}{l}1 \\
1\end{array}$ & $\begin{array}{l}\mathrm{Fe}^{+++} \\
\mathrm{Fe}^{++}\end{array}$ & $\begin{array}{l}976,000 \\
848,000\end{array}$ & $\begin{array}{l}1.1 \\
6.3\end{array}$ & 5.7 \\
\hline & $\begin{array}{l}1 / 7 / 44 \\
1 / 25 / 44\end{array}$ & & $\begin{array}{l}7.18 \\
7.30\end{array}$ & $\begin{array}{l}15.8 \\
16.5\end{array}$ & $\begin{array}{l}48 \\
49\end{array}$ & $\begin{array}{l}1 \\
1\end{array}$ & $\begin{array}{l}\mathrm{Fe}^{++} \\
\mathrm{Fe}^{+++}\end{array}$ & $\begin{array}{l}1,992,000 \\
1,512,000\end{array}$ & $\begin{array}{l}7.6 \\
3.7\end{array}$ & 2.1 \\
\hline 41 & $\begin{array}{r}12 / 31 / 43 \\
1 / 25 / 44\end{array}$ & 12.3 & $\begin{array}{l}5.40 \\
5.26\end{array}$ & $\begin{array}{l}16.0 \\
14.5\end{array}$ & $\begin{array}{l}47 \\
43\end{array}$ & $\begin{array}{l}1 \\
1\end{array}$ & $\begin{array}{l}\mathrm{Fe}^{+++} \\
\mathrm{Fe}^{++}\end{array}$ & $\begin{array}{l}2,945,000 \\
2,016,000\end{array}$ & $\begin{array}{l}2.7 \\
5.0\end{array}$ & 1.8 \\
\hline 44 & $\begin{array}{r}12 / 31 / 43 \\
1 / 17 / 44\end{array}$ & 14.1 & $\begin{array}{l}5.73 \\
5.84\end{array}$ & $\begin{array}{l}15.8 \\
14.4\end{array}$ & $\begin{array}{l}46 \\
44\end{array}$ & $\begin{array}{l}\mathbf{1} \\
\mathbf{1}\end{array}$ & $\begin{array}{l}\mathrm{Fe}^{++} \\
\mathrm{Fe}^{+++}\end{array}$ & $\begin{array}{l}2,945,000 \\
2,344,000\end{array}$ & $\begin{array}{l}4.8 \\
5.2\end{array}$ & 0.9 \\
\hline
\end{tabular}

* Highest value reached.

ferric or the ferrous state. At the time of the second dose, a fairly constant level of labeled iron had been reached in the blood as a result of the first dose. The increase above this level which followed the second administration was taken to be the percentage of absorption of the second dose.

\section{ABSORPTION OF FERROUS AND FERRIC IRON BY THE DOG}

Six normal dogs were given $1 \mathrm{mgm}$. per $\mathrm{kgm}$. of either ferrous or ferric radioactive iron and the appearance of the labeled element as newly.synthesized hemoglobin in the peripheral blood was determined as a measure of the amount absorbed. After 2 to 3 weeks, each animal was fed a comparable dose of the valence form not given at the first administration, and the observations were repeated. Determinations were made on small samples of blood (5 to $10 \mathrm{ml}$.), collected at intervals of 3 days.

The results of these experiments are summarized in Table $I$, and representative data are charted in Figures 1 and 2. It will be observed, first of all, that the quantities of iron absorbed by these "normal" dogs were usually several times greater than the fraction of 1 per cent reported by Hahn and his associates $(26,27)$. There are several possible explanations for these differences. The 6 animals used may not have had adequate iron reserves although they had been given vermifuges and had been kept in individual cages on a Purina dog chow diet for weeks before being used. Their erythrocyte, hemoglobin, and hematocrit levels were well within the normal range. They were not, however, made "plethoric" by transfusion nor given iron supplements prior to the experiments. The test dose of iron, furthermore, was given in solution by stomach tube, to the fasting dog. In the studies reported by Hahn and co-workers $(26,27)$, the iron was mixed with food and fed, a practice which provided more favorable conditions for the formation of insoluble forms of iron in the intestinal tract (38). The differences in the absolute amount of iron absorbed, however, do not influence the following comparison between the relative absorption of the 2 valence forms. In 6 of 9 comparisons made in the 6 animals, more ferrous than ferric iron was assimilated while in 


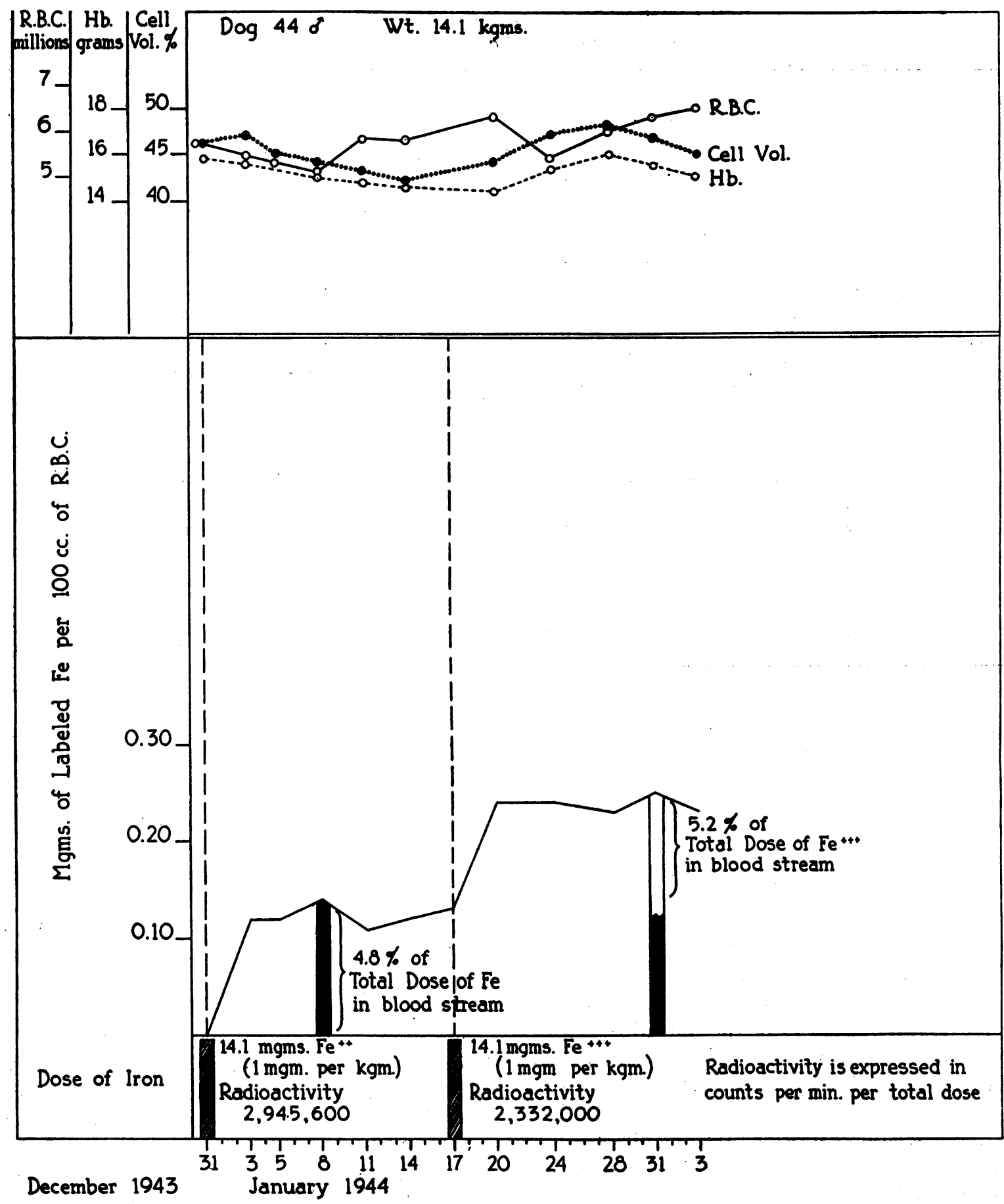

Fig. 1. Absorption of Ferrous and Ferric Iron by a Normal Dog

In this and subsequent figures, the "labeled" or radioactive iron is charted in terms of mgm. per $100 \mathrm{cc}$. of red cells. The solid black vertical bar represents the percentage of the first test dose present in the calculated circulating blood volume. In order to estimate the percentage of iron absorbed from the second dose, it was necessary to assume that the quantity of radioactive iron present in the blood as the result of the first dose remained constant throughout the second period. The percentage absorbed from the second dose is represented by the clear portion of the second vertical bar. Any error which results because the curves are superimposed would tend to make the figure for absorption during the second period lower than it should be. 


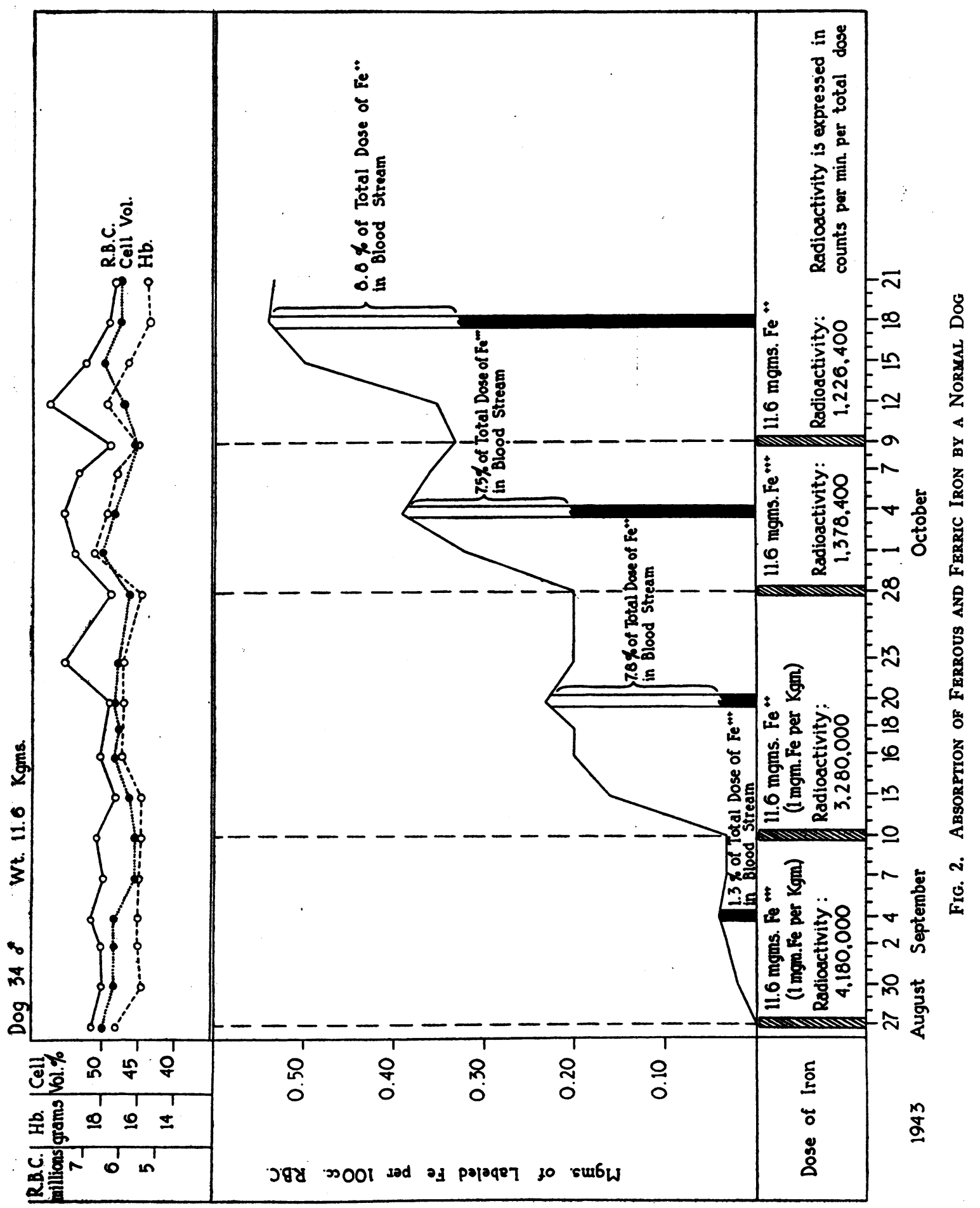




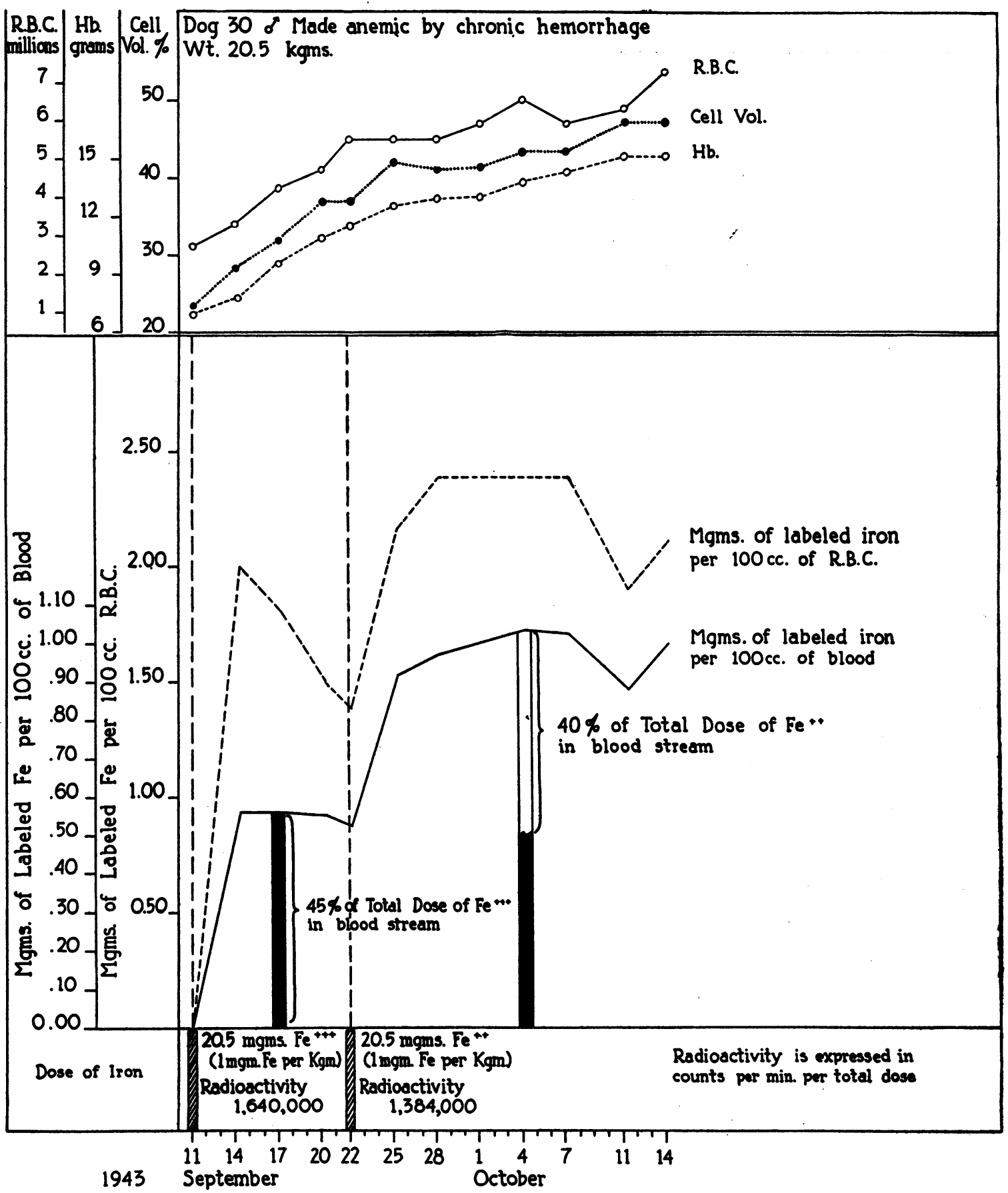

Fig. 3. Absorption of Ferrous and Ferric Iron by an Anemic Dog

the other 3 comparisons, almost equal amounts of the 2 forms were absorbed (Figure 1, Table I). Two sets of determinations were made on Dogs 32, 34, and 38. More ferrous than ferric iron was absorbed by Dogs 32 and 34 at the time of the first comparison (Figure 2), whereas in the second set of experiments, no difference existed. The explanation for the greater assimilation of ferrous salts on one occasion in these animals is not clear. Certainly the amount of blood with- 
TABLE II

Absorption of ferric and ferrous iron by dogs made anemic by chronic hemorrhage

\begin{tabular}{|c|c|c|c|c|c|c|c|c|c|c|}
\hline Dog & Date & Wt. & R.B.C. & Hgb. & Cell vol. & Dose of $\mathrm{Fe}$ & $\begin{array}{c}\text { Valence } \\
\text { of } \\
\text { iron }\end{array}$ & Radioactivity & $\begin{array}{l}\text { Labeled iron } \\
\text { in blood } \\
\text { stream* }\end{array}$ & $\begin{array}{l}\text { Ratio of amount } \\
\text { of } \mathrm{Fe}^{++} \text {to } \\
\mathrm{Fe}^{+++} \text {absorbed }\end{array}$ \\
\hline & & kgm. & millions & grams & per cent & $\underset{\mathrm{kgm} .}{\operatorname{mgm} . \text { per }}$ & & $\begin{array}{l}\text { counts per min. } \\
\text { of total dose }\end{array}$ & per cent & \\
\hline 15 & $\begin{array}{l}4 / 7 / 41 \\
4 / 19 / 41\end{array}$ & 13.6 & $\begin{array}{l}4.00 \\
3.96\end{array}$ & $\begin{array}{l}7.6 \\
7.5\end{array}$ & $\begin{array}{l}25 \\
25\end{array}$ & $\begin{array}{l}3.6 \\
3.6\end{array}$ & $\begin{array}{l}\mathrm{Fe}^{++} \\
\mathrm{Fe}^{+++}\end{array}$ & $\begin{array}{l}\mathbf{9 , 5 4 0 \dagger} \\
\mathbf{8 , 4 0 0}\end{array}$ & $\begin{array}{l}10.8 \\
11.3\end{array}$ & 1.0 \\
\hline 21 & $\begin{array}{l}6 / 29 / 43 \\
7 / 29 / 43\end{array}$ & 13 & $\begin{array}{l}2.67 \\
4.75\end{array}$ & $\begin{array}{l}4.5 \\
6.2\end{array}$ & $\begin{array}{l}17 \\
21\end{array}$ & $\begin{array}{l}1 \\
1\end{array}$ & $\begin{array}{l}\mathrm{Fe}^{+++} \\
\mathrm{Fe}^{++}\end{array}$ & $\begin{array}{l}8,135,000 \\
3,920,000\end{array}$ & $\begin{array}{l}21.7 \\
22.5\end{array}$ & 1.0 \\
\hline 30 & $\begin{array}{l}9 / 11 / 43 \\
9 / 22 / 43\end{array}$ & 20.5 & $\begin{array}{l}2.71 \\
5.5\end{array}$ & $\begin{array}{r}6.9 \\
11.4\end{array}$ & $\begin{array}{l}23 \\
37\end{array}$ & $\begin{array}{l}1 \\
1\end{array}$ & $\begin{array}{l}\mathrm{Fe}^{+++} \\
\mathrm{Fe}^{++}\end{array}$ & $\begin{array}{l}1,640,000 \\
1,384,000\end{array}$ & $\begin{array}{l}45.0 \\
40.4\end{array}$ & 0.9 \\
\hline 31 & $\begin{array}{l}8 / 13 / 43 \\
8 / 25 / 43\end{array}$ & 16.8 & $\begin{array}{l}2.75 \\
6.15\end{array}$ & $\begin{array}{r}5.6 \\
12.2\end{array}$ & $\begin{array}{l}24 \\
43\end{array}$ & $\begin{array}{l}1 \\
1\end{array}$ & $\begin{array}{l}\mathrm{Fe}^{++} \\
\mathrm{Fe}^{+++}\end{array}$ & $\begin{array}{l}1,952,000 \\
1,680,000\end{array}$ & $\begin{array}{l}29.5 \\
19.1\end{array}$ & 1.5 \\
\hline
\end{tabular}

* Highest value reached.

† Made with Bale dip type counter.

drawn for determinations was not great enough to have influenced materially their iron reserves.

Similar observations were made on 4 anemic dogs whose iron reserves had been depleted by systematic bleeding. The test dose of radioactive iron was $1 \mathrm{mgm}$. per $\mathrm{kgm}$. of body weight in $3 \mathrm{dogs}$ and $3.6 \mathrm{mgm}$. per $\mathrm{kgm}$. in the fourth. In all instances, there was: (1) greater assimilation than had occurred in the "normal" dogs, and (2) approximately equal assimilation of the 2 valence forms (Table II, Figure 3). It will be noted, however, that Dog 31 absorbed 29 per cent of the ferrous salt and only 19 per cent of the ferric. The ferric test dose, however, was given after the animal had almost recovered from his anemia; this fact may, partially at least, have accounted for the difference.

Under the conditions of these experiments,

TABLE III

Absorption of ferric and ferrous iron by healthy men

\begin{tabular}{|c|c|c|c|c|c|c|c|c|c|}
\hline $\begin{array}{c}\text { Subject. } \\
\text { age }\end{array}$ & Date & R.B.C. & Hgb. & Cell vol. & Dose of $\mathrm{Fe}$ & $\begin{array}{c}\text { Valence } \\
\text { of } \\
\text { iron }\end{array}$ & Radioactivity & $\begin{array}{l}\text { Labeled iron } \\
\text { in blood } \\
\text { stream* }\end{array}$ & $\begin{array}{l}\text { Ratio of amount } \\
\text { of } \mathrm{Fe}^{++} \text {to } \\
\mathrm{Fe}^{+++} \text {absorbed }\end{array}$ \\
\hline years & & millions & grams & per cent & $\underset{\mathrm{kgm} .}{\operatorname{mgm} . \text { per }}$ & & $\begin{array}{l}\text { counts per min. } \\
\text { of total dose }\end{array}$ & per cent & 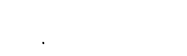 \\
\hline$\underset{23}{\text { EHK. }}$ & $\begin{array}{l}4 / 30 / 42 \\
5 / 18 / 42\end{array}$ & $\begin{array}{l}5.37 \\
4.87\end{array}$ & $\begin{array}{l}16.2 \\
15.5\end{array}$ & $\begin{array}{l}47 \\
46 z\end{array}$ & $\begin{array}{l}4 \\
4\end{array}$ & $\begin{array}{l}\mathrm{Fe}^{+++} \\
\mathrm{Fe}^{++}\end{array}$ & $\begin{array}{l}427,200 \\
316,000\end{array}$ & $\begin{array}{l}0.8 \\
8.0\end{array}$ & 10 \\
\hline $\begin{array}{l}\text { JRC. } \\
22\end{array}$ & $\begin{array}{l}4 / 30 / 42 \\
5 / 18 / 42\end{array}$ & $\begin{array}{l}5.32 \\
5.05\end{array}$ & $\begin{array}{l}16.0 \\
15.9\end{array}$ & $\begin{array}{l}48 \\
47 \frac{1}{2}\end{array}$ & $\begin{array}{l}4 \\
4\end{array}$ & $\begin{array}{l}\mathrm{Fe}^{++} \\
\mathrm{Fe}^{+++}\end{array}$ & $\begin{array}{l}315,200 \\
233,600\end{array}$ & $\begin{array}{l}5.9 \\
3.4\end{array}$ & $1 \frac{1}{2}$ \\
\hline$\underset{28}{\text { LWM. }}$ & $\begin{array}{l}10 / 22 / 42 \\
11 / 14 / 42\end{array}$ & $\begin{array}{l}4.67 \\
4.61\end{array}$ & $\begin{array}{l}14.5 \\
14.0\end{array}$ & $\begin{array}{l}43 \\
43\end{array}$ & $\begin{array}{l}4 \\
4\end{array}$ & $\begin{array}{l}\mathrm{Fe}^{+++} \\
\mathrm{Fe}^{++}\end{array}$ & $\begin{array}{l}6,240,000 \\
4,410,000\end{array}$ & $\begin{array}{l}0.9 \\
4.6\end{array}$ & 5 \\
\hline$\underset{33}{\text { CVM. }}$ & $\begin{array}{l}2 / 3 / 42 \\
2 / 24 / 42\end{array}$ & $\begin{array}{l}4.74 \\
4.65\end{array}$ & $\begin{array}{l}15.4 \\
15.3\end{array}$ & $\begin{array}{l}46 \\
47\end{array}$ & $\begin{array}{l}4 \\
4\end{array}$ & $\begin{array}{l}\mathrm{Fe}^{+++} \\
\mathrm{Fe}^{++}\end{array}$ & $\begin{array}{l}970,000 \\
821,000\end{array}$ & $\begin{array}{l}4.4 \\
9.5\end{array}$ & 2 \\
\hline$\underset{34}{\text { CVM. }}$ & $\begin{array}{l}10 / 21 / 42 \\
11 / 11 / 42\end{array}$ & $\begin{array}{l}5.25 \\
5.20\end{array}$ & $\begin{array}{l}16.2 \\
17.2\end{array}$ & $\begin{array}{l}47 \\
49\end{array}$ & $\begin{array}{l}2 \\
2\end{array}$ & $\begin{array}{l}\mathrm{Fe}^{+++} \\
\mathrm{Fe}^{++}\end{array}$ & $\begin{array}{l}3,840,000 \\
3,152,000\end{array}$ & $\begin{array}{r}2.2 \\
11.2\end{array}$ & 5 \\
\hline $\mathrm{JO}_{23}$ & $\begin{array}{l}5 / 1 / 42 \\
5 / 18 / 42\end{array}$ & $\begin{array}{l}4.96 \\
5.01\end{array}$ & $\begin{array}{l}16.2 \\
15.8\end{array}$ & $\begin{array}{l}47 \\
48\end{array}$ & $\begin{array}{l}2 \\
2\end{array}$ & $\begin{array}{l}\mathrm{Fe}^{++} \\
\mathrm{Fe}^{+++}\end{array}$ & $\begin{array}{l}213,600 \\
162,400\end{array}$ & $\begin{array}{r}10.6 \\
3.5\end{array}$ & 3 \\
\hline$\underset{22}{\text { TGS. }}$ & $\begin{array}{l}7 / 2 / 42 \\
7 / 18 / 42\end{array}$ & $\begin{array}{l}5.21 \\
4.57\end{array}$ & $\begin{array}{l}14.7 \\
14.1\end{array}$ & $\begin{array}{l}46 \\
42\end{array}$ & $\begin{array}{l}2 \\
2\end{array}$ & $\begin{array}{l}\mathrm{Fe}^{+++} \\
\mathrm{Fe}^{++}\end{array}$ & $\begin{array}{r}1,080,000 \\
854,000\end{array}$ & $\begin{array}{l}0.3 \\
1.1\end{array}$ & 3 \\
\hline CCJ. & $\begin{array}{l}11 / 26 / 43 \\
12 / 24 / 43\end{array}$ & $\begin{array}{l}5.39 \\
5.20\end{array}$ & $\begin{array}{l}15.5 \\
15.6\end{array}$ & $\begin{array}{l}48 \frac{1}{2} \\
48 \frac{1}{2}\end{array}$ & 1 & $\begin{array}{l}\mathrm{Fe}^{++} \\
\mathrm{Fe}^{+++}\end{array}$ & $\begin{array}{l}9,876,000 \\
6,672,000\end{array}$ & $\begin{array}{l}9.3 \\
1.4\end{array}$ & 7 \\
\hline$\underset{23}{\text { GB. }}$ & $\begin{array}{l}11 / 26 / 43 \\
12 / 24 / 43\end{array}$ & $\begin{array}{l}5.53 \\
5.56\end{array}$ & $\begin{array}{l}17.9 \\
16.4\end{array}$ & $\begin{array}{l}54 \\
50\end{array}$ & $\begin{array}{l}1 \\
1\end{array}$ & $\begin{array}{l}\mathrm{Fe}^{+++} \\
\mathrm{Fe}^{++}\end{array}$ & $\begin{array}{l}9,876,000 \\
6,672,000\end{array}$ & $\begin{array}{l}1.3 \\
8.1\end{array}$ & 6 \\
\hline
\end{tabular}

* Highest value reached. 


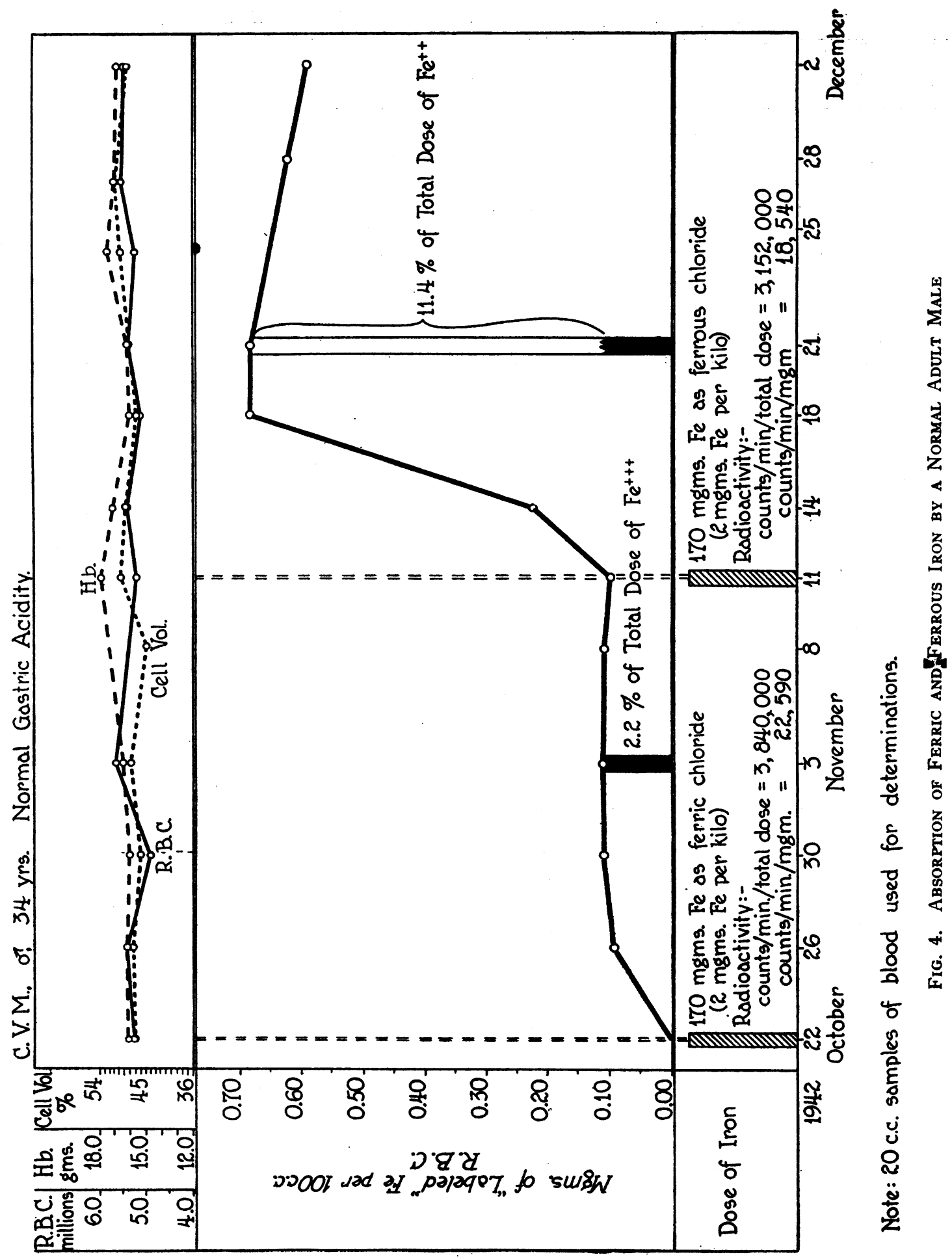


TABLE IV

Absorption of ferric and ferrous iron by subjects with hypochromic anemia

\begin{tabular}{|c|c|c|c|c|c|c|c|c|c|}
\hline $\begin{array}{l}\text { Subject, } \\
\text { age }\end{array}$ & Date & R.B.C. & Hgb. & Cell vol. & Dose of Fe & $\begin{array}{c}\text { Valence } \\
\text { of } \\
\text { iron }\end{array}$ & Radioactivity & $\begin{array}{c}\text { Labeled iron } \\
\text { in blood } \\
\text { stream* }\end{array}$ & $\begin{array}{l}\text { Ratio of amount } \\
\text { of } \mathrm{Fe}^{++} \text {to } \\
\mathrm{Fe}^{+++} \text {absorbed }\end{array}$ \\
\hline years & & millions & grams & per cent & $\underset{\text { kgm. }}{\operatorname{mgm} . \text { per }}$ & & $\begin{array}{c}\text { counts per min. } \\
\text { of total dose }\end{array}$ & per cent & \\
\hline$\underset{16}{\mathrm{MBW}}$ & $\begin{array}{l}10 / 24 / 42 \\
11 / 21 / 42\end{array}$ & $\begin{array}{l}3.65 \\
3.78\end{array}$ & $\begin{array}{l}8.7 \\
7.6\end{array}$ & $\begin{array}{l}30 \\
29\end{array}$ & $\begin{array}{l}4 \\
4\end{array}$ & $\begin{array}{l}\mathrm{Fe}^{+++} \\
\mathrm{Fe}^{++}\end{array}$ & $\begin{array}{l}5,150,000 \\
3,564,000\end{array}$ & $\begin{array}{r}3.5 \\
11.9\end{array}$ & 3 \\
\hline $\begin{array}{l}\text { RLB. } \\
38\end{array}$ & $\begin{array}{l}11 / 23 / 42 \\
12 / 15 / 42\end{array}$ & $\begin{array}{l}4.23 \\
4.36\end{array}$ & $\begin{array}{l}5.7 \\
5.6\end{array}$ & $\begin{array}{l}27 \\
27\end{array}$ & $\begin{array}{l}4 \\
4\end{array}$ & $\begin{array}{l}\mathrm{Fe}^{+++} \\
\mathrm{Fe}^{++}\end{array}$ & $\begin{array}{l}226,000 \\
173,000\end{array}$ & $\begin{array}{r}4.3 \\
13.1\end{array}$ & 3 \\
\hline AL. & $\begin{array}{l}11 / 21 / 42 \\
12 / 21 / 42\end{array}$ & $\begin{array}{l}3.53 \\
3.57\end{array}$ & $\begin{array}{l}7.0 \\
7.8\end{array}$ & $\begin{array}{l}26 \\
28\end{array}$ & $\begin{array}{l}2 \\
2\end{array}$ & $\begin{array}{l}\mathrm{Fe}^{+++} \\
\mathrm{Fe}^{++}\end{array}$ & $\begin{array}{l}254,000 \\
194,000\end{array}$ & $\begin{array}{r}1.9 \\
29.4\end{array}$ & 15 \\
\hline $\begin{array}{r}\text { AR. } \\
38\end{array}$ & $\begin{array}{r}12 / 5 / 42 \\
1 / 4 / 43\end{array}$ & $\begin{array}{l}3.29 \\
3.52\end{array}$ & $\begin{array}{l}9.3 \\
9.2\end{array}$ & $\begin{array}{l}30 \\
31\end{array}$ & $\begin{array}{l}2 \\
2\end{array}$ & $\begin{array}{l}\mathrm{Fe}^{+++} \\
\mathrm{Fe}^{++}\end{array}$ & $\begin{array}{l}6,060,000 \\
4,380,000\end{array}$ & $\begin{array}{r}6.2 \\
26.1\end{array}$ & 4 \\
\hline$\underset{38}{M L}$ & $\begin{array}{l}9 / 13 / 43 \\
9 / 29 / 43\end{array}$ & $\begin{array}{l}4.41 \\
4.59\end{array}$ & $\begin{array}{l}9.1 \\
9.2\end{array}$ & $\begin{array}{l}35 \\
33\end{array}$ & $\begin{array}{l}1 \\
1\end{array}$ & $\begin{array}{l}\mathrm{Fe}^{+++} \\
\mathrm{Fe}^{++}\end{array}$ & $\begin{array}{l}4,442,500 \\
3,225,000\end{array}$ & $\begin{array}{l}17.0 \\
39.7\end{array}$ & 2 \\
\hline
\end{tabular}

* Highest value reached.

therefore, the dog may either absorb both valence forms of iron equally well or show preferential assimilation of the ferrous form. It is of interest that equal absorption was obtained on all 4 of the anemic dogs but in only one-third of the experiments on normal animals. The fact that the ferrous form was more efficiently assimilated in roughly half of the experiments is compatible with the concept that the dog must reduce ingested iron to the bivalent state before absorbing it. If reduction is slow or incomplete, decreased absorption of ferric iron may result. Further work will be necessary to test the validity of this explanation.

\section{ABSORPTION OF FERROUS AND FERRIC IRON BY THE HUMAN SUBJECT}

Comparison of the absorption of radioactive ferrous and ferric iron was made 9 times on 8 different adult male subjects. The test doses used were 1,2 , and $4 \mathrm{mgm}$. of iron per $\mathrm{kgm}$. of body weight and were always given after a 12 hour fast. Adult males were selected to avoid the complication of blood loss incident to menstruation in women. The erythrocyte, hemoglobin, and hematocrit values were normal in all instances. In each case, more ferrous than ferric iron was absorbed; the ratio $\mathrm{Fe}^{++}$to $\mathrm{Fe}^{+++}$ assimilated varied from $1 \frac{1}{2}$ to 10 (Table III, Figure 4). It is also worth noting that only 2 subjects absorbed less than 5 per cent of the ferrous test dose.

Similar studies were made on 5 patients with severe degrees of hypochromic microcytic anemia (Table IV, Figures 5 and 6). Absorption of the bivalent form was 2 to 15 times as great as that of the ferric form. Note should also be made of the fact that, as in animal experiments $(26,27)$, the percentage assimilated was greater with the small than with the large doses. There was a distinct tendency, furthermore, for these irondeficient subjects to assimilate iron more completely than did the normal adult males.

These results confirm, therefore, the conclusion of clinical investigators (1 to 13$)$ that the human subject absorbs ferrous iron more efficiently than ferric.

\section{DISCUSSION}

In the debate between clinical and animal investigators as to the valence form in which iron is absorbed from the intestinal tract, no single group of investigators has previously studied both human subjects and animals. The present study represents such an investigation and has used what seems to be the best method available for quantitating iron absorption. Human subjects were shown to absorb ferrous iron more efficiently than ferric iron. Dogs assimilated both valence forms equally well in 7 out of 13 comparisons; in the other 6 experiments, more ferrous than ferric iron was absorbed.

There are 3 possible explanations for the greater absorption of bivalent iron by the human: (1) only ferrous iron may be absorbed and all trivalent iron may have to be reduced before it 


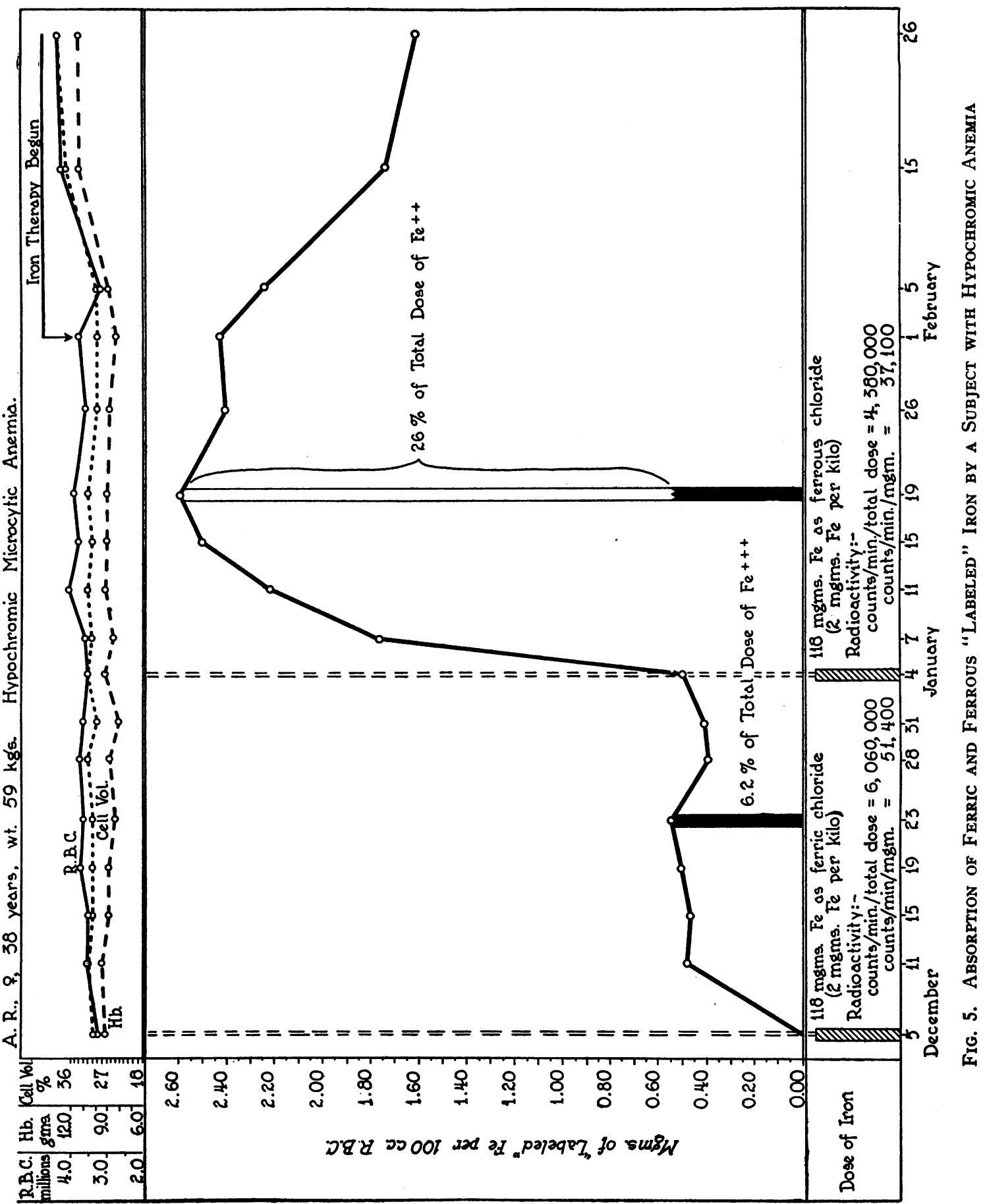




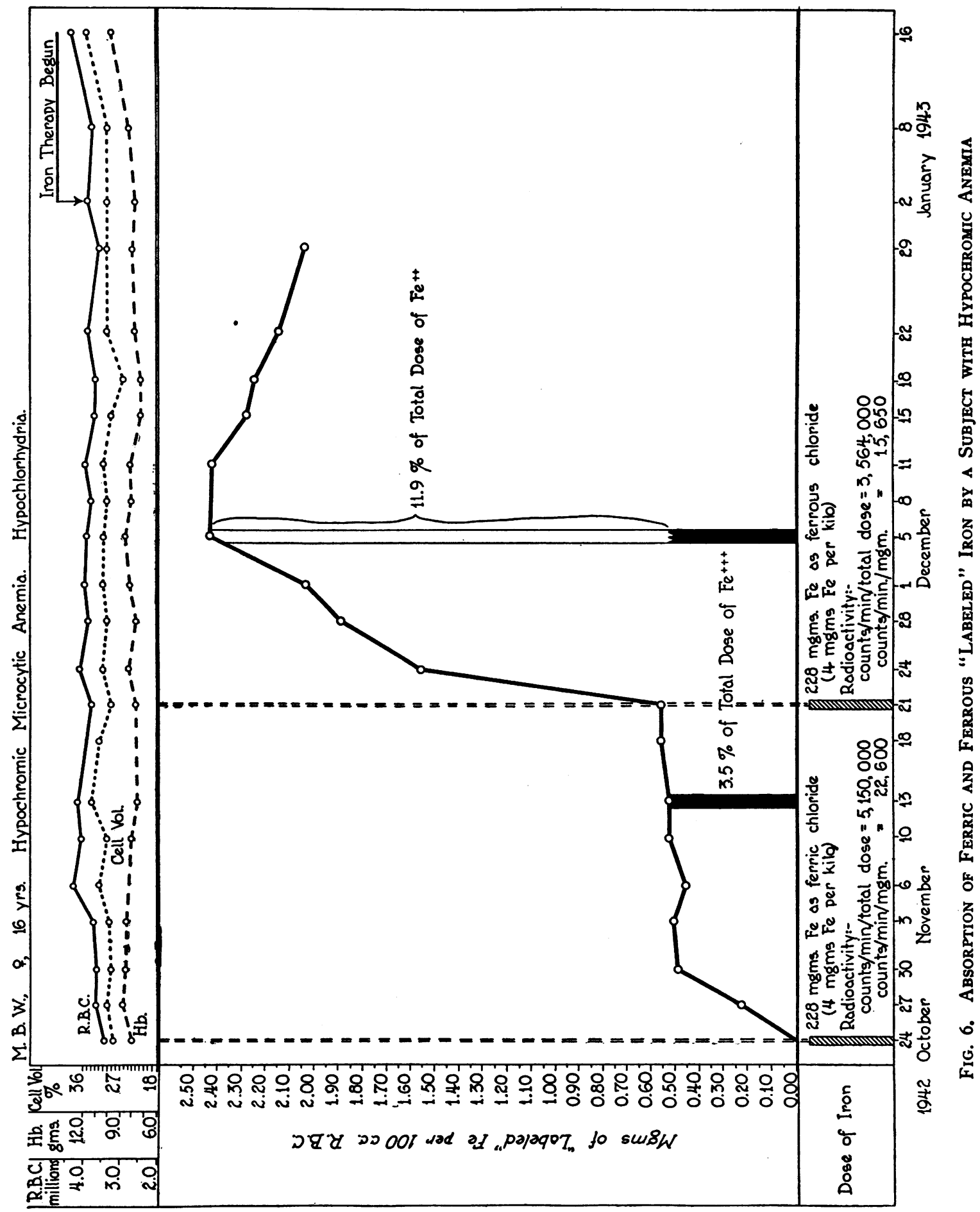


can be taken up by the body; (2) both forms may be absorbed but to an unequal degree; and (3) ferric iron may be made less available for absorption because it more readily forms complex insoluble compounds within the intestinal tract. How the dog differs from the human so that it frequently can absorb ferrous and ferric iron equally well can only be conjectured. The dog may reduce ferric iron more efficiently than does the human. Its intestinal mucosa may absorb both forms without distinction or conditions may be less favorable for the formation of insoluble ferric compounds. It has been reported that rats absorb radioactive ferrous and ferric iron equally well (18). Whatever the reasons, the data help provide an explanation for the different opinions expressed by human and animal investigators. When discussion is made of the valence form in which iron is most readily absorbed from the intestinal tract, the discussion must be related specifically to the species of animal under consideration.

\section{SUMMARY}

Comparison was made in the same "normal" and iron-deficient human subjects and in the same "normal" and iron-deficient dogs of the degree to which comparable test doses of ferrous and ferric radioactive iron were assimilated. The quantity of iron given varied from 1 to 4 $\mathrm{mgm}$. of iron per $\mathrm{kgm}$. of body weight and the administration was made under fasting conditions. The amount of radioactive iron which subsequently appeared as hemoglobin in the peripheral blood was used as the measure of the amount absorbed. Under these conditions, human subjects absorbed $1 \frac{1}{2}$ to 15 times more ferrous than ferric iron, while dogs either absorbed both valence forms to a comparable degree or showed preferential assimilation of ferrous salts. Because species of animals have been shown to differ in this respect, discussion of the valence form in which iron is most readily absorbed from the intestinal tract should be related to the species under consideration.

\section{BIBLIOGRAPHY}

1. Reimann, F., and Fritsch, F., Vergleichende Untersuchungen zur therapeutischen Wirksamkeit der
Eisenverbindungen bei den sekundären Anämien. Ztschr. f. klin. Med., 1930, 115, 13.

2. Davidson, L. S. P., Discussion on the treatment of the anaemias. Classification. Proc. Royal Soc. Med., 1933, 26, 616.

3. Lottrup, M. C., Treatment of anemia in children with ferric and ferrous compounds, reduced iron and cupric sulphate. Am. J. Dis. Child., 1934, 47, 1.

4. Fullerton, H. W., The treatment of hypochromic anemia with soluble ferrous salts. Edinburgh $\mathbf{M}$. J., 1934, 41, 99.

5. Witts, L. J., The therapeutic action of iron. Lancet, $1936,1,1$.

6. Heath, C. W., and Patek, A. J., Jr., The anemia of iron deficiency. Medicine, 1937, 16, 267.

7. Smith, C. H., Sedimentation rate in nutritional anemia of infants and children. Its response to treatment with iron (ferrous sulfate). Am. J. Dis. Child., 1938, 56, 510.

8. Davidson, L. S. P., and Fullerton, H. W., Chronic nutritional hypochromic anemia. Edinburgh M. J., 1938, 45, 193.

9. Fowler, W. M., and Barer, A. P., Treatment of iron deficiency anemias. J.A.M.A., 1939, 112, 110.

10. Wintrobe, M. M., Clinical Hematology. Lea and Febiger, Philadelphia, 1942, p. 292.

11. Heilmeyer, L., and Plötner, H., Eisenmangelzustände und ihre Behandlung. Klin. Wchnschr., 1936, 15, 1669.

12. Moore, C. V., Arrowsmith, W. R., Welch, J., and Minnich, V., Studies in iron transportation and metabolism. IV. Observations on the absorption of iron from the gastro-intestinal tract. J. Clin. Invest., 1939, 18, 553.

13. McCance, R. A., Edgecombe, C. N., and Widdowson, E. M., Phytic acid and iron absorption. Lancet, 1943, 2, 126.

14a. Whipple, G. H., and Robscheit-Robbins, F. S., Blood regeneration in severe anemia. XVI. Optimum iron therapy and salt effect. Am. J. Physiol., 1930, 92, 362 .

b. Idem, Iron and its utilization in experimental anemia. Am. J. M. Sc., 1936, 191, 11.

15. Hahn, P. F., and Whipple, G. H., Iron metabolism: Its absorption, storage and utilization in experimental anemia. Am. J. M. Sc., 1936, 191, 24.

16. Underwood, E. J., A comparison of ferrous and ferric iron in the nutrition of the rat. J. Nutrition, 1938, 16, 299.

17. Street, H. R., A study of the availability of the iron in enriched bread. J. Nutrition, 1943, 26, 187.

18. Austoni, M. E., and Greenberg, D. M., Studies in iron metabolism with the aid of its artificial radioactive isotope. The absorption, excretion, and distribution of iron in the rat on normal and iron-deficient diets. J. Biol. Chem., 1940, 134, 27.

19. Mitchell, H. S., and Vaughn, M., The relation of inorganic iron to nutritional anemia. J. Biol. Chem., 1927, 75, 123. 
20. Simmonds, N., Becker, J. E., and McCollum, E. V., The relation of vitamin $E$ to iron assimilation. J.A.M.A., 1927, 88, 1047.

21a. Heubner, W., Bemerkung zur Eisentherapie. Ztschr. f. klin. Med., 1924, 100, 675.

b. Idem; Uber "organische" Eisenpraparate. Klin Wchnschr., 1926, 5, 588.

22a. Lintzel, W., Neuere Ergebnisse der Erforschung des Eisenstoffwechsels. Ergebn. d. Physiol., 1931, 31, 844.

b. Idem, Zum Nachweis der Resorption des Nahrungseisens als Ferroion. Biochem. Ztschr., 1933, 263, 173.

23. Eichholtz, F. and Unrath, H., Uber Eisenkatalysen. III. Perorale Zufuhr. Arch. f. exper. Path. u. Pharmakol., 1935, 178, 154.

24. Fürth, O., and Scholl, R., The absorption of ferrous and ferric compounds from the intestines of rabbits. J. Pharmacol. and Exper. Therap., 1936, 58, 14.

25. Cosyns, H., Etude comparée des courbes de résorption des sels ferreux et des sels ferriques. Compt. rend. Soc. d. biol., 1939, 130, 786.

26. Hahn, P. F., Ross, J. F., Bale, W. F., and Whipple, G. H., The utilization of iron and the rapidity of hemoglobin formation in anemia due to blood loss. J. Exper. Med., 1940, 71, 731.

27. Hahn, P. F., Bale, W. F., Lawrence, E. O., and Whipple, G. H., Radioactive iron and its metabolism in anemia. Its absorption, transportation, and utilization. J. Exper. Med., 1939, 69, 739.

28. Hahn, P. F., Bale, W. F., Ross, J. F., Hettig, R. A., and Whipple, G. H., Radio-iron in plasma does not exchange with hemoglobin iron in red cells. Science, 1940, 92, 131.

29. Copp, D. H., A study of iron metabolism with the aid of the radioactive isotope $\mathrm{Fe}^{\mathrm{bs}}$. Summary of the dissertation submitted in partial satisfaction of the requirements for the Degree of Doctor of Philosophy. Univ. of Calif., Graduate Division, Northern ern Section, 1943.

30. Hahn, P. F., Bale, W. F., Hettig, R. A., Kamen, M. D., and Whipple, G. H., Radioactive iron and its excretion in urine, bile and feces. J. Exper. Med., 1939, 70, 443.

31. Greenberg, D. M., Copp, D. H., and Cuthbertson, E. M., Studies in mineral metabolism with the aid of artificial radioactive isotopes. VII. The distribution and excretion, particularly by way of the bile, of iron, cobalt, and manganese. J. Biol. Chem., 1943, 147, 749.

32. Hamilton, J. G., The use of radioactive tracers in biology and medicine. Radiology, 1942, 39, 541.

33. Whipple, G. H., and Robscheit-Robbins, F. S., Blood regeneration in severe anemia. I. Standard basal ration bread and experimental methods. Am. J. Physiol., 1925, 72, 395.

34. Ray, T. W., A rapid means of obtaining manganesefree iron. J. Lab. and Clin. Med., 1940, 25, 745.

35. Ross, J. F., and Chapin, M. A., The electrolytic separation of radioactive iron from the blood. Rev. Scient. Instruments, 1942, 13, 77.

36. Bale, W. F., Haven, F., and LeFevre, M. L., Apparatus for the rapid determination of beta ray activity in solutions. Rev. Scient. Instruments, 1939, 10, 193.

37. Hahn, P. F., Balfour, W. M., Ross, J. F., Bale, W. F., and Whipple, G. H., Red cell volume circulating and total as determined by radio iron. Science, 1941, 93, 87.

38. Smythe, C. V., and Schmidt, C. L. A., Studies on the mode of combination of iron with certain proteins, amino acids and related compounds. J. Biol. Chem., 1930, 88, 241. 